\title{
Leader Humor Behavior and Organizational Citizenship Behavior: Mediation Mechanism of Leader-Member Exchange
}

\author{
Fitri Yunita ${ }^{a,}{ }^{*}$ Bambang Supeno ${ }^{b, *}$ \\ ${ }^{a}$ Magister of Management, Graduate Program, Universitas Lancang Kuning, Indonesia.
}

\begin{tabular}{|c|c|}
\hline ABSTRACT & ARTICLE HISTORY \\
\hline $\begin{array}{l}\text { This study aims to analyze the influence of the leader's humorous behavior } \\
\text { and organizational citizenship behavior and the mediating role of the } \\
\text { leader-member exchange. The location of this research was carried out in } \\
\text { one of the government agencies in the city of Pekanbaru - Riau. While the } \\
\text { time of the study was carried out from April to May 2021. The source of this } \\
\text { research data is employee respondents at one of the government agencies } \\
\text { in the city of Pekanbaru - Riau. With } 39 \text { respondents as the research sample. } \\
\text { Data analysis techniques are descriptive analysis, convergent and } \\
\text { discriminant validity tests and reliability tests, with PLS Structural Equation } \\
\text { Modeling (SEM) analysis which is operated through the SmartPLS program. } \\
\text { The results of this study show that Leader Humor Behavior has a positive } \\
\text { effect which can encourage employees to be involved in Organizational } \\
\text { Citizenship Behavior (OCB) in one of the government agencies in the city of } \\
\text { Pekanbaru - Riau and Leader-Member Exchange (LMX) is able to mediate } \\
\text { the relationship between Leader Humor Behavior and Organizational } \\
\text { Citizenship Behavior (OCB) for employees in one of the government } \\
\text { agencies in the city of Pekanbaru-Riau. }\end{array}$ & $\begin{array}{l}\text { KEYWORDS } \\
\text { Leader Humor Behavior, } \\
\text { Organizational Citizenship } \\
\text { Behavior and Leader-Member } \\
\text { Exchange }\end{array}$ \\
\hline
\end{tabular}

\section{Introduction}

One of the things that play a role in assembling an interesting personality is humor. Use of humor in social interactions, communicating, and interacting with others. Hill (in Darmansyah, 2012) states that a high sense of humor is one of the most important parts to assemble an attractive personality in interacting with other people. When leaders are in the office, they are actually also communicating socially with their subordinates. Social communication will be dry and stiff if it is not interspersed with humor. Shapiro (in Darmansyah, 2012) states that humor can communicate likes or dislikes and can be used to express positive or negative feelings about other people. According to the Ministry of National Education (2008) humor is the ability to feel something funny or fun. Allport was the first character to use the term sense of humor, explaining that sense of humor is the ability to see oneself objectively, be amused and able to laugh at one's inferiority, hostility and socially unacceptable desires (in Harsono, 2011). Martin (2007) defines humor as all things said or done that cause funny things and try to make other people laugh, as well as mental processes 
in terms of making and receiving pleasant stimuli and also affective responses that also include pleasure in it.

Organizations that succeed in bringing about change have the characteristics of being able to move faster, aware of the importance of commitment to product quality improvement, increased involvement of organizational members, customer orientation, and organizations whose structure leads to an increasingly flat and not pyramidal shape. Organizations need the right strategic planning, so that success can be achieved (Nashori, 2009). The achievement of organizational goals is largely determined by the behavior of the people in the organization. Everyone has duties and responsibilities aimed at achieving the goals of carrying out functions within the organization. Everyone in the organization is required to have a commitment so that organizational functions run as expected so that the planned goals can be achieved. Worker behaviors are conceptually distinguished as in-role (task dependent behavior) and extra-role (individual behavior that exceeds the expected standard of behavior). Kartz (in Sumiyarsih, 2012), emphasizes that cooperative and helpful behaviors that are outside the formal requirements are very important for the functioning of the organization. Additional behaviors outside of job descriptions in organizations are often referred to as organizational citizenship behavior or Organizational Citizenship Behavior (OCB).

The behavior of employees in an organization is divided into three categories by Huang et al. (2012), namely: (a) employees who participate, are bound and are in an organization; (b) employees who must complete a job and act in accordance with the principles set by the organization; and (c) employees who engage in innovative and spontaneous activities that exceed their perceived role in the organization. Employees who fall into the last category are often referred to as employees who have Organizational Citizenship Behavior (OCB) or employees who have extra-role behavior (Huang et al., 2012). According to Robbins (2008), Organizational Citizenship Behavior (OCB) is a preferred behavior that is not part of an employee's formal work obligations, but supports the effective functioning of the organization. In other words, OCB is a positive behavior for non-formal companies because employees help voluntarily outside of the formal work that has been given by the organization without any rewards. Examples of behaviors that include OCB are helping individuals on a team, volunteering to do extra work, protecting organizational property, avoiding unnecessary conflict, respecting the spirit and content of the rules, providing constructive suggestions in the workplace, and willingly tolerating harm. and occasional work-related distractions. Organ (1988), defines OCB as individual behavior that is independent (discretionary), which is not directly or explicitly rewarded by the formal reward system, and which overall encourages the effectiveness of organizational functions. Robbins et al. (2013) define OCB as behavior that benefits the organization and or intends to benefit the organization that directly leads to the role of expectations. Some specific examples of behavior of employees who have good OCB such as willingness to help new employees identify and understand their work area, provide examples of attendance, make timely suggestions to the right parties and in the right forum 
for more efficient operations, being able to act to prevent or resolve conflicts between coworkers, or spontaneously help co-workers who have problems or urgent tasks (Organ, 2015). According to Podsakoff, et al (2000), factors that influence OCB are individual characteristics (including job satisfaction, commitment, perception of the organization, motivation and personality), task characteristics and organizational characteristics (including organizational culture and climate, organizational support, group cohesiveness), and leadership characteristics (including leadership support and behavior, quality of superior-subordinate relationships).

OCB behavior can be in the form of helping coworkers who are having trouble at work, replacing coworkers who don't come in or taking breaks, helping colleagues whose work is overloaded, helping other people's work when they don't come in, being on time every day no matter the season or the past. cross section, assisting the orientation process of new employees even though they are not asked, not spending time on conversations outside of work, willingness to tolerate without complaining, refraining from complaining and swearing activities, paying attention to important meetings. (Aldag \& Resckhe, 1997).

Leader-member exchange theory (LMX, Leader-Member Exchange) explains the process of creating roles between leaders and subordinates and the exchange relationships that develop over time (Yukl, 2015: 140).

\section{Theoretical support}

\section{Social Exchange Theory (SET)}

Social Exchange Theory (SET) is one of the most influential conceptual paradigms in understanding the work behavior of employees in an organization. Empirical studies of social exchange theory can be traced to the period of the 1920s Malinowski (1922); Mauss (1925). One of the figures who developed the theory of social exchange, among others, is psychology (Blau, 1964). Furthermore, it is said that social exchange is a feeling that causes a common perception of future goals. In view of this theory, employees will be motivated and committed to work and the organization if they are treated fairly and equally. Furthermore, Bass (1990) stated that SET theory is aimed at understanding the relationship between leaders and their subordinates and understanding the factors related to documents (Mowdey et.al., 1982).

\section{Leadership}

Leadership is part of management functions that occupy strategic positions in the system and work hierarchy and responsibilities in an organization. There are several kinds of understanding about leadership, including according to Wukir (2013), giving the notion of leadership which is the art of motivating and influencing a group of people to act towards a common goal. Stating that leadership has a positive effect. The implementation of good leadership will make the organizational culture better state by (Rahmat, 2015). 


\section{Leader's Humor Behavior}

Humor is a valuable character strength possessed by leaders (Copper \& Sosik, 2012). Humor behavior is conceptually defined as "any event that an agent (eg an employee) shares with another individual (i.e. a target) that is intended to entertain the target and the target perceives as a deliberate act" (Cooper, 2005, p. 767). Humor is a very diverse and complex phenomenon. From a management perspective, humor is seen as a social communication that is intended and intentional to entertain others (Cooper et al., 2018).

\section{Organizational Citizenship Behavior (OCB)}

Organizational Citizenship Behavior (OCB) is part of the science of organizational behavior, OCB is a form of work behavior that is usually not seen or taken into account. There are two approaches to the OCB concept, namely OCB is an extra role performance that is separate from in-role performance or performance according to the job description. The second approach is to view OCB from a political principle or philosophy. This approach identifies the behavior of organizational members with citizenship behavior. The existence of OCB is the impact of individual beliefs and perceptions in the organization on the fulfillment of psychological agreements and contracts. This behavior arises because the individual feels as a member of the organization who has a sense of satisfaction when he can do something more than the organization (Saleem and Amin, 2013).

\section{Leader-Member Exchange (LMX)}

In an organization, subordinates and leaders exchange social resources (social resources) based on the consequences of benefits received by both parties (Abdillah, 2021). The perception held by subordinates regarding whether voluntary actions on their part will be returned or not by superiors someday. Internal leaders and subordinates to maintain equality between inputs and outputs to fulfill their obligations in social interactions (Abdillah et al., 2020). The exchange process will then form a strong relationship and positive work attitudes and behaviors. In high-quality social exchange relationships, mutual trust, respect and obligation to return/provide balanced resources tend to occur. Thus, subordinates with a high perception of Leader-Member Exchange tend to carry out voluntary roles beyond the formal duties that are their obligations because they feel they get social resources from their leaders (Dulebohn et al., 2012).

\section{Research method}

\section{Explanatory Study Research}

This research is an explanatory study, namely research that aims to explain why an event occurs and to build, expand, elaborate or test theory (Neuman, 2011). This study aims to explain the mechanism that underlies the relationship between interpersonal conflict and the behavior of hiding knowledge based on theory. In other words, this research is an explanatory 
research that uses quantitative methods to test hypotheses empirically. In social research, especially in the field of management, quantitative method is a research method rooted in the positivist social science approach which "emphasizes discovering causal law, careful empirical observations and value-free research" (Neuman, 2014, p. 97). This study then utilizes a crosssectional survey in collecting research data to test the formulated hypotheses. This study uses quantitative methods by explaining that the research paradigm emphasizes understanding of problems in social life based on conditions of reality or natural settings that are holistic, complex and detailed. The nature of this research is descriptive and verification, describing the characteristics of the variables studied and testing the truth of a hypothesis.

\section{Results}

\section{Analisis SEM-PLS}

Data analysis in this study tested the effect of several independent variables on the dependent variable and the moderating variable. Hypothesis testing is done by using the method Partial Least Square (PLS). Partial Least Square is the solution method Structural Equation Modelling (SEM). Research entitled the influence of Lonely on Organizational Citizenship Behavior with Commit as moderating on employees of one company PT. Green Planet Indonesia. In analyzing the research data using SEM analysis with the WarpPLS 5.0 application. The steps in analyzing the data are as follows:

a. Outer Model

Data management in this study uses PLS (partial least square) where the dependent variable is Organizational Citizenship Behavior (Y), while the independent variable is Leader Humor Behavior (X), and the mediating variable is Leader-Member Exchange (M). The fit model is used with the aim of testing the overall level of suitability of the research model. Testing the significance of the independent variable on the test dependent variable can be declared significant by fulfilling the requirements if the $P$ value is less than 0.05 .

Table 1. Analisis Outer Model Fit.

\begin{tabular}{lll}
\hline Model & Fit Indices & P Values \\
\hline APC & 0.645 & $\mathrm{P}<0.001$ \\
ARS & 0.918 & $\mathrm{P}<0.001$ \\
\hline \multicolumn{2}{c}{ Notes. Processed Data 2021 } &
\end{tabular}

The output in table 1 shows that the fit model indicators with APC 0.645, ARS 0.918 and P valuese $\mathrm{P}<0.001$ are declared significant because they meet a significant value of 0.05 .

b. Combined Loading and Cross Loading

Variables with low loading values indicate that the indicator does not have a good effect on reflective indicators $>0.7$ while the formative variables of each variable provide the largest contribution to the construct. At 5\% alpha and t-statistic $>1.96$. Cross loading is another measure of discriminant validity. The results of the combined loading and cross loading 
test are that the reflective and formative indicators in this study have a p-value of $<0.001$ on all research variables, and are declared significant because $<0.05$.

c. Average Variance External

Table 2. Analysis of Average Variance Extracted (AVE)

\begin{tabular}{ccc}
\hline $\mathrm{PH}$ & $\mathrm{OCB}$ & $\mathrm{LMX}$ \\
\hline 0.881 & 0.562 & 0.915 \\
\hline Notes. Processed Data 2021 & &
\end{tabular}

Based on table 2 which states that AVE can be used to measure the amount of variance in the construct compared to the variance generated in the measurement. The results of the AVE test in this study were $\mathrm{X}$ worth 0.881 ; $\mathrm{Y}$ is 0.562 ; and $\mathrm{M}$ is worth 0.915 . The AVE value for all variables has exceeded 0.05 , so it can be said that it has met the standard of the AVE value.

d. Inner Model

Inner model is an analysis conducted to test the research hypothesis and answer the problems posed. Hypothesis testing is carried out according to the research framework carried out to analyze and test directly and indirectly between exogenous and endogenous variables with a moderation model. The significance level of testing this hypothesis is done by looking at the value of the p-value.

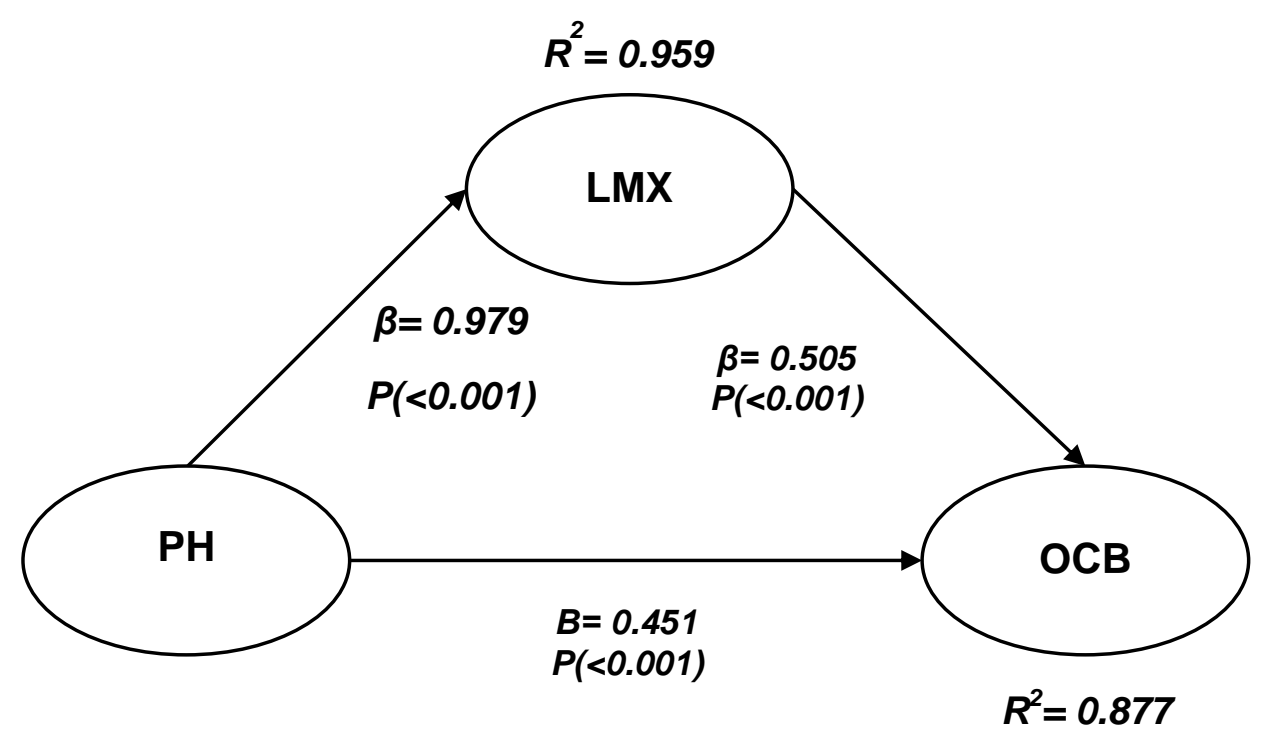

Figure 1. Structural Equation.

Figure 1 shows the results of the path coefficients with a significance level in accordance with the calculations that have been carried out using Warp PLS, so it can be concluded as in table 4 below: 
Table 3. Analysis of Path coefficient and $p$ values

\begin{tabular}{|c|c|c|c|c|c|}
\hline \multicolumn{2}{|c|}{ Relationship between variables } & \multicolumn{2}{|c|}{ Path Coefficient } & \multicolumn{2}{|c|}{ Significance Level } \\
\hline Exogenous & Endogenous & Coeff. & $P$-value & value & Description \\
\hline$P H(\mathrm{X})$ & OCB $(Y)$ & 0.451 & 0.001 & $<0.001$ & Significant \\
\hline$P H(\mathrm{X})$ & $L M X(M)$ & 0.979 & 0.001 & $<0.001$ & Significant \\
\hline$O C B(Y)$ & $L M X(M)$ & 0.505 & 0.001 & $<0.001$ & Significant \\
\hline$P H * O C B$ & $\operatorname{LMX}(M)$ & 0.494 & 0.001 & $<0.001$ & Mediation \\
\hline
\end{tabular}

Based on Table 3 shows the calculation of the influence of the leader's Humor Behavior variable that has a positive effect on Organizational Citizenship Behavior (OCB). In this calculation, the path coefficient value is 0.451 with a significance level or $p$-value $<0.001$. The calculation explains that the hypothesis of Leader Humor Behavior has a positive effect on Organizational Citizenship Behavior (OCB) and is accepted and the relationship is positive. This means that the Leader's Humorous Behavior (X) has a significant effect on Organizational Citizenship Behavior (Y), the higher the Leader's Humorous Behavior, the higher the Organizational Citizenship Behavior or vice versa.

Calculation of the influence of the leader's Humor Behavior variable has a positive effect on the Leader-Member Exchange (LMX). In this calculation, the path coefficient value is 0.979 with a significance level or p-value $<0.001$. The calculation explains that the hypothesis of Leader Humor Behavior has a positive effect on the Leader-Member Exchange (LMX) is accepted and the relationship is positive. This means that the Leader's Humorous Behavior (X) has a significant effect on the Leader-Member Exchange (M), the higher the Leader's Humorous Behavior, the higher the Leader-Member Exchange (LMX) or vice versa.

Calculation of the influence of the variable Organizational Citizenship Behavior (OCB) has a positive effect on the Leader-Member Exchange (LMX). In this calculation, the path coefficient value is 0.505 with a significance level or $\mathrm{p}$-value $<0.001$. The calculation explains that the Organizational Citizenship Behavior (OCB) hypothesis has a positive effect on the Leader-Member Exchange (LMX) is accepted and the relationship is positive. This means that directly Organizational Citizenship Behavior (OCB) (Y) has a significant effect on the LeaderMember Exchange (M), the higher the Humor Behavior of the Leader, the higher the LeaderMember Exchange (LMX) or vice versa.

Calculation of the influence of the Leader-Member Exchange (LMX) variable as a mediating variable of Leader Humor Behavior on Organizational Citizenship Behavior (OCB). In this calculation, the path coefficient value is 0.494 with a significance level or $p$-value $<0.001$. The calculation explains that the Leader-Member Exchange (LMX) hypothesis as a mediating variable of Leader Humor Behavior on Organizational Citizenship Behavior (OCB) is accepted and the relationship is positive. This means that indirectly Leader-Member Exchange 
(LMX) as a mediating variable of Leader Humor Behavior on Organizational Citizenship Behavior (OCB), this shows the role of Leader-Member Exchange (LMX) where the greater the Leader's Humor Behavior and Organizational Citizenship Behavior (OCB). This results in an increase in the Leader-Member Exchange (LMX).

\section{Discussions}

\section{The Influence of Leaders' Humor Behavior on Organizational Citizenship Behavior (OCB)}

Calculation of the influence of the Leader's Humor Behavior variable has a positive effect on Organizational Citizenship Behavior (OCB). In this calculation, the path coefficient value is 0.451 with a significance level or $\mathrm{p}$-value $<0.001$. The calculation explains that the hypothesis of Leader Humor Behavior has a positive effect on Organizational Citizenship Behavior (OCB) and is accepted and the relationship is positive. This means that the Leader's Humorous Behavior (X) has a significant effect on Organizational Citizenship Behavior (Y), the higher the Leader's Humorous Behavior, the higher the Organizational Citizenship Behavior or vice versa. The results of this study are in line with previous studies of Cooper et al. (2018) who found that leader's humorous behavior can encourage subordinates to engage in Organizational Citizenship Behavior (OCB). This is because this leader's humorous behavior can encourage subordinates to engage in knowledge sharing behavior (Abdillah, 2021).

\section{Leader-Member Exchange (LMX) Mediating the Leader's Humorous Behavior Relationship with Organizational Citizenship Behavior (OCB)}

Calculation of the influence of the Leader-Member Exchange (LMX) variable as a mediating variable of Leader Humor Behavior on Organizational Citizenship Behavior (OCB). In this calculation, the path coefficient value is 0.494 with a significance level or p-value $<0.001$. The calculation explains that the Leader-Member Exchange (LMX) hypothesis as a mediating variable of Leader Humor Behavior on Organizational Citizenship Behavior (OCB) is accepted and the relationship is positive. This means that indirectly Leader-Member Exchange (LMX) as a mediating variable of Leader Humor Behavior towards Organizational Citizenship Behavior (OCB), this shows the role of Leader-Member Exchange (LMX) where the greater the Leader's Humor Behavior towards Organizational Citizenship Behavior (OCB). This results in an increase in the Leader-Member Exchange (LMX). The results of this study are in line with Cooper et al. (2018) who found that Leader-Member Exchange (LMX) mediates the

relationship between leader's humor behavior and Organizational Citizenship Behavior (OCB). The study explains that the leader's humorous behavior causes the quality of the Leader-Member Exchange (LMX) relationship which in turn encourages employees to engage in Organizational Citizenship Behavior (OCB). Based on these results, this study has the effect that the leader's humorous behavior will lead to a high quality of Leader-Member Exchange (LMX) which in turn will encourage employees to engage in Organizational Citizenship Behavior (OCB). 


\section{Effect of Affective Commitment on Organizational Citizenship Behavior}

Calculation of the effect of the affective commitment variable has a positive effect on Organizational Citizenship Behavior. In this calculation, the path coefficient value is 0.223 with a significance level or p-value $<0.001$. The calculation explains that the Affective Commitment hypothesis has a positive effect on Organizational Citizenship Behavior and is accepted and the relationship is positive. This means that directly Affective Commitment $(\mathrm{Z})$ has a significant effect on Organizational Citizenship Behavior (Y), the higher the employee's affective commitment, the higher the Organizational Citizenship Behavior or vice versa.

\section{Conclusion}

It can be concluded that the leader's humorous behavior has a positive effect that can encourage employees to be involved in Organizational Citizenship Behavior (OCB) in one of the government agencies in the city of Pekanbaru - Riau. Leader-Member Exchange (LMX) is able to mediate the relationship between Leader Humor Behavior and Organizational Citizenship Behavior (OCB) in employees in one government agency in Pekanbaru - Riau. From the results of a questionnaire that has been distributed to 39 employees at one of the government agencies in the city of Pekanbaru - Riau, Leader Humor Behavior and Organizational Citizenship Behavior (OCB) are variables that must be considered. With the results obtained that the Leader's Humor Behavior is in the High interval and the Organizational Citizenship Behavior (OCB) is in the Very High interval, the results of this study can help leaders in an effort to improve the performance of their employees.

\section{Acknowledgement}

We thank the anonymous reviewers for their valuable support and guidance in improving the quality of the paper. Furthermore, we thank Adi Rahmat and Muhammad Rasyid Abdillah for his feedback on earlier versions of the paper. Besides, we also thank Universitas Lancang Kuning, Indonesia, for their assistance and support along the undertaken of this research.

\section{Disclosure statement}

No potential conflict of interest was reported by the authors.

\section{References}

Abdillah, M. R., Lin, C. T., Anita, R., Suroto, B., \& Hadiyati, H. (2018). Knowledge-sharing behavior among banking officers in Indonesia. Journal of International Studies, 11(2).

Abdillah, M. R., Wu, W., \& Anita, R. (2020). Can altruistic leadership prevent knowledge-hiding behaviour? Testing dual mediation mechanisms. Knowledge Management Research \& Practice, 1-15.

Abdillah, M. R., Anita, R., \& Zakaria, N. B. (2020). Authentic leader and internal whistleblowers: testing a dual mediation mechanism. International Journal of Ethics and Systems.

Abdillah, M. R. (2021). Leader Humor and Knowledge Sharing Behavior: The Role of Leader-Member Exchange. Jurnal Manajemen, Volume XXV(01).

Aldag, R., \& Reschke, W. (1997). Employee value added. Center for organizational effectiveness Inc. 
Alfaidah, F. (2007). Pengaruh kepuasan kerja karyawan terhadap produktivitas kerja pada koperasi Agro Niaga Jabung Malang. Tugas Akhir, Fakultas Ekonomi, Jurusan Manajemen Universitas Islam Negeri (UIN) Malang.

Almigo, N. (2004). Hubungan antara kepuasan kerja dengan produktivitas kerja karyawan. Jurnal Psyche, 1(1). Baidan, Nasharuddin \& Erwati Aziz. (2014). Etika Islam dalam Berbisnis, Yogyakarta, Pustaka Pelajar.

Blau, P. M. (1964). Exchange and power in social life. New York, NY: John Wiley.

Brislin, R. W. (1980). Cross-cultural research methods. In Environment and culture (pp. 47-82). Springer, Boston, MA.

Bourque, L., \& Fielder, E. P. (2003). How to conduct self-administered and mail surveys (Vol. 3). Sage.

Chin, W. W. (2010). How to write up and report PLS analyses. In Handbook of partial least squares (pp. 655690). Springer, Berlin, Heidelberg.

Cooper, C. D. (2005). Just joking around? employee humor expression as an ingratiatory behavior. In Academy of Management Review (Vol. 30, Issue 4, pp. 765-776). Academy of Management. https://doi.org/10.5465/AMR.2005.18378877.

Cooper, C. D., and Sosik, J. J. (2012). The laughter advantage: Cultivating high quality connections and workplace outcomes through humor. In The handbook of positive organizational scholarship (pp. 474-489). Oxford University Press. https://doi.org/10.1093/OXFORDHB/9780199734610.013.0036.

Cooper, C. D., Kong, D. T., \& Crossley, C. D. (2018). Leader humor as an interpersonal resource: Integrating three theoretical perspectives. Academy of Management Journal, 61(2).

Cropanzano, R., \& Mitchell, M. S. (2005). Social exchange theory: An interdisciplinary review. Journal of management, 31(6).

Darmansyah. (2012). Strategi pembelajaran menyenangkan dengan humor. Jakarta: Bumi Aksara.

Deckop, J. R., Mangel, R., \& Cirka, C. C. (1999). Getting more than you pay for: Organizational citizenship behavior and pay-for-performance plans. Academy of Management journal, 42(4).

Departemen Pendidikan Nasional. (2008). Kamus besar bahasa indonesia pusat bahasa. Edisi Keempat. Jakarta: PT Gramedia Pustaka Utama.

Dulebohn, J. H., Bommer, W. H., Liden, R. C., Brouer, R. L., \& Ferris, G. R. (2012). A meta-analysis of antecedents and consequences of leader-member exchange: Integrating the past with an eye toward the future. Journal of management, 38(6).

Fink, A. (2003). The survey handbook. sage.

Fredrickson, B. L. (2001). The role of positive emotions in positive psychology: The broaden-and-build theory of positive emotions. American psychologist, 56(3).

Halbesleben, J. R., Neveu, J. P., Paustian-Underdahl, S. C., \& Westman, M. (2014). Getting to the "COR" understanding the role of resources in conservation of resources theory. Journal of management, 40(5).

Hair Jr, J. F., Sarstedt, M., Hopkins, L., \& Kuppelwieser, V. G. (2014). Partial least squares structural equation modeling (PLS-SEM): An emerging tool in business research. European business review.

Harsono, S. B. D. (2011). Hubungan sense of humor dengan stress pada mahasiswa psikologi yang sedang menyusun skripsi. Skripsi tidak diterbitkan. Fakultas Psikologi Universitas Katolik Soegijapranata. Semarang.

Hobfoll, S. E. (1989). Conservation of resources: a new attempt at conceptualizing stress. American psychologist, 44(3).

Hobfoll, S. E. (2002). Social and psychological resources and adaptation. Review of general psychology, 6(4).

Huang, C.-C., You, C.-S., Tsai, M.-T. (2012). A multidimensional analysis of ethical climate, job satisfaction, organizational commitment, and organizational citizenship behaviors. Nursing Ethics 19.

Hughes, R. L., Ginnett, R. C., \& Curphy, G. J. (2012). Leadership: Memperkaya pelajaran dari pengalaman. Edisi Ketujuh, Jakarta: Salemba Humanika.

Klein, K. J., \& Kozlowski, S. W. (2000). Multilevel theory, research, and methods in organizations: Foundations, extensions, and new directions. Jossey-Bass. 
Kock, N. (2015). Common method bias in PLS-SEM: A full collinearity assessment approach. International Journal of e-Collaboration (ijec), 11(4), 1-10.

Komang Ardana, Ni Wayan Mujiati, dan Agung Ayu Sriathi. (2009). Perilaku Organisasi, Yogyakarta; Graha Ilmu,h.101-102.

Koontz, Harold, Cyril O’Donnel dan Henz Weihrich. (1984). Management. Singapore: McGrawHill Inc.

Martin, R. A. (2007). The psychology of humor: an integrative approach. USA: Elsvier Academic Press.

Martoyo, Susilo. (2000). Manajemen Sumber Daya Manusia. Jogjakarta: PT BPFE - JogJakarta.

Munandar, A. S. (2001). Psikologi industri dan organisasi. Jakarta: UI Press/.

Nashori, F. (2009). Psikologi kepemimpinan. Yogyakarta: Pustaka Fahima.

Neuman, W. Lawrence. (2011). Social Research Methods: Qualitative and Quantitative Approaches. 7th Edition, Pearson, Boston.

Neuman, W. Lawrence. (2013). Metodologi Penelitian Sosial Pendekatan Kualitatif dan Kuantitatif Edisi 7. Jakarta: Indeks.

Neuman, W. Lawrence. (2014). Basics of social research. Pearson/Allyn and Bacon.

Newstrom, J. W. (2011). Organizational behavior (13th ed.). New York, NY: McGrawHill.

O'Cass, A., \& Weerawardena, J. (2010). The effects of perceived industry competitive intensity and marketingrelated capabilities: Drivers of superior brand performance. Industrial Marketing Management, 39(4), 571-581.

Organ, D.W. (1988). Organizational citizenship behavior: The good soldier syndrome. Lexington Books/DC Heath and Com, London.

Organ, D.W. 2015. Organizational Citizenship Behavior, Vol 17. Elsevier, Oxford.

Podsakoff, P. M., et al. (2000). Organizational Citizenship Behavior: A Critical Review of The Theoretical and Empirical Literature and Suggestions for Future Research. Journal of Management, Vol. 26, No. 3.

Podsakoff, P. M., MacKenzie, S. B., Lee, J. Y., \& Podsakoff, N. P. (2003). Common method biases in behavioral research: a critical review of the literature and recommended remedies. Journal of applied psychology, 88(5), 879.

Podsakoff, P. M., MacKenzie, S. B., \& Podsakoff, N. P. (2012). Sources of method bias in social science research and recommendations on how to control it. Annual review of psychology, 63, 539-569.

Putri dan Nurul. (2010). Manajemen Sumber Daya Manusia. Bandung: Remaja Rosda Karya.

Rahmat, A. (2015). Pengaruh Kepemimpinan Dan Budaya Kerja Dalam Membentuk Komitmen Karyawan. Jurnal Ilmiah Ekonomi dan Bisnis (e-journal), 12(1).

Rahmawati, Eka Nuraini. (2004). Paradigma Baru Manajemen Sumber Daya Manusia Sebagai Basis Meraih Keunggulan Kompetitif. Yogyakarta: Ekonisia.

Rauch Jr, C. F., \& Behling, O. (1984). Functionalism: Basis for an alternate approach to the study of leadership. In Leaders and managers (pp. 45-62). Pergamon.

Rivai Vietzal. (2003). Kepemimpinan dan Perilaku Organisasi, Jakarta, PT Grafindo Persada.

Rivai Vietzal \& Mulyadi, D. (2012). Kepemimpinan dan Perilaku Organisasi edisi ketiga. Jakarta: PT. Rajagrafindo Persada.

Rivai Vietzal, Bahtiar dan Boy Rafli Amar. (2013). Pemimpin dan Kepemimpinan dalam Organisasi, Jakarta; PT Raja Grafindo Persada.

Robbins, Marjorie, et al. (2008). Misinterpreting the therapeutic effects of small interfering RNA caused by immune stimulation. Human gene therapy, 19(10), 991-999.

Robbins, S., Judge, T.A., Millett, B., Boyle, M. (2013). Organisational Behavior. Pearson Higher Education AU, England.

Ruvendi, R. (2005). Imbalan dan gaya kepemimpinan pengaruhnya terhadap kepuasan kerja karyawan di Balai Besar Industri Hasil Pertanian Bogor. Jurnal ilmiah binaniaga, 1(1).

Saleem, Sharjeel and Saba Amin. (2013). The Impact of Organizational Support for Career Development and Supervisory Suppoert on Employee Performance : An Emperical Study From Pakistani Academic Sector. Europen Journal of Business and Management. 5 (5). 
Samsudin, Sadili. (2010). Manajemen Sumber Daya Manusia. Bandung: Pustaka Setia.

Santrock, J. W. (2002). Attachment related psyhodynamics. Attachment and human development. Edisi ke 8. New Jersey.

Sofyandi, H., \& Garniwa, I. (2007). Perilaku organisasional. Yogyakarta: Graha Ilmu.

Solihin, M., \& Ratmono, D. (2013). Analisis SEM-PLS dengan warppls 3.0. Yogyakarta: Andi Yogyakarta.

Solimun, Achmad, Adji. R. F, Nurjannah. (2017). Metode Statistika Multivariat Pemodelan Persamaan Struktural (SEM) Pendekatan WarpPLS. Malang: UB Press.

Stevens, S. S. (1946). On the theory of scales of measurement. Sains . 103 (2684): 677-680.

Sugiyono. (2011). Metode Penelitian Kuantitatif, Kualitatif, dan R\&D. Bandung: Alfabeta.

Sugiyono. (2013). Metode Penelitian Pendidikan Pendekatan Kuantitatif, Kualitatif, dan R\&D. Bandung: Alfabeta.

Sugiyono. (2017). Metode Penelitian Kuantitatif, Kualitatif, dan R\&D. Bandung: Alfabeta.

Sumiyarsih, W., Mujiasih, E., \& Ariati, J. (2012). Hubungan antara kecerdasan emosional dengan organizational citizenship behavior (OCB) pada karyawan CV. Aneka Ilmu Semarang. J Psikol Undip, 11(1).

Tenenhaus, M., Vinzi, V. E., Chatelin, Y. M., \& Lauro, C. (2005). PLS path modeling. Computational statistics \& data analysis, 48(1), 159-205.

Terry, G. R. (1960). Principles of Management. Homewood, Ill: Richard D. Irwin.

Terry, R. (2010). George dan Leslie W. Rue. Dasar-Dasar Manajemen.

Thoha, M. (1983). Perilaku Organisasi; Konsep Dasar dan Aplikasinya, Cetakan Pertama. Rajawali. Jakarta.

Usman Effendi. (2011). Asas Manajemen, Jakarta; PT Raja Grafindo,h.188-189.

Van Dyne, L., \& Ang, S. (1998). Organizational citizenship behavior of contingent workers in Singapore. Academy of management Journal, 41(6), 692-703.

West, Richard \& Lynn H. Tunner. (2008). Pengantar Teori Komunikasi : Analisis dan Aplikasi. Jakarta: Salemba Humanika.

Wetzels, M., Odekerken-Schröder, G., \& Van Oppen, C. (2009). Using PLS path modeling for assessing hierarchical construct models: Guidelines and empirical illustration. MIS quarterly, 177-195.

Wukir. (2013). Manajemen Sumber Daya Manusia Dalam Organisasi Sekolah. Yogyakarta: Multi Presindo.

Yukl, Gary. (2005). Kepemimpinan Dalam Organisasi. Edisi 5. Jakarta: PT.Indeks.

Yukl, Gary. (2015) Kepemimpinan Dalam Organisasi. Edisi 7. Jakarta : PT.Indeks.

Zakiy, Muhammad. (2015). Pengaruh Ketidakpastian Psikologis Karyawan Terhadap Kepuasan Kerja dan Intensi Keluar dari Organisasi dengan Leader Member Exchange (LMX) Sebagai Variabel Pemoderasi. Tesis S2 Magister Manajemen Universitas Gajah Mada. 